\title{
International trade and Economic growth: cross-country evidence
}

\author{
Dushko Josheski ${ }^{1}$ \\ Darko Lazarov $^{2}$
}

\begin{abstract}
Many empirical studies have been done to investigate whethere growth is influenced by international trade. But despite the great effort that has been devoted to studying the issue, there is little persuasive evidence concerning the effect of trade on growth. The main subject of our paper is to summarize the main findings based on empirical research that have been done to investigate the relationship between the trade and economic growth by using data for 208 regions and countries in OLS regression analysis.

Our results from empirical investigation show: 1) the ratio of trade volume (sum of exports and imports at current prices-current openness or sum of exports plus sum of imports) to GDP as a proxy of trade openness has positive effect on economic growth, 2) black market premium as a proxy for imbalance in macroeconomic policies has negative effect, 3 ) in the presence of macroeconomic policies, trade has statistically and economic significant positive influence on growth, and 4) in an institutional environment trade lacks influencing growth, the coefficient on institutions is positive and statistically significant.
\end{abstract}

Keywords: International trade, economic growth, institutions, macroeconomic imbalances

\section{Introduction}

Starting from Adam Smith's discussion on specialization and the extant of the market by international trade, to the debates about import substitution versus exported growth (growth based on exporting more goods and services), to recent work on increasing returns and endogenous growth models, there are increasing debates among economists about the international trade and economic growth.

The advances in growth theory avoid (enable) economists to focus on some issues that have long been central to international economics. In addition, we will present some of those issues; 1) to what extent and in what ways, international trade might be "engine of growth"?, 2) Do international exchanges of goods and services naturally enhance the growth performance of individual trading countries? And what economic policies are especially conductive to high levels of income in a growing, open economy?

\footnotetext{
${ }^{1}$ (Goce Delcev University -Shtip)

Email: dushkojosheski@gmail.com

2 (Goce Delcev University -Shtip)

Email:darko.lazarov@ugd.com

*Received 28 June 2012; accepted 17 September 2012
} 
Some theoretical backgrounds of the global economy seem especially important for understanding growth performance in context of endogenous growth models (when growth is based on firms' incentives to invest in creation of knowledge). ${ }^{3}$ First, comparative advantage may determine to what extent particular counties are led to specialize in the creation of knowledge and in the production of goods that make incentives use of human capital and new technologies. Second, the large scale of the world economy provides great opportunities for the exploitation of research successes and enhancing the incentives that firms have to invest in the generation of new technologies. Third, in a world of rapid and cheap communication, ideas and information spread very quickly across international borders. Countries stand to benefit from the spillovers generated by investments in knowledge in trade partner counties. Finally, participation in international capital markets provides an expanded set of opportunities for financing investments in all forms of capital, including knowledge capital.

The aspects of international trade environment that we have mentioned above we only use as a theoretical background of our empirical research, the research of transmission effects of trade to economic growth is not our primary goal in this paper.

\section{Empirical literature overview}

Over the past decades relationship between trade and growth had been of interest among the economists. In the next Table we present the selected studies and their main findings.

\begin{tabular}{|l|c|l|}
\hline \multicolumn{1}{|c|}{ Study } & \multicolumn{1}{|c|}{ Technique } & \multicolumn{1}{c|}{ Main findings } \\
\hline Kwan and Cotsomitis (1991) & $\begin{array}{l}\text { Granger causality test to } \\
\text { study Chinese growth and } \\
\text { foreign trade }\end{array}$ & $\begin{array}{l}\text { output was an exogenous variable } \\
\text { and there was a one-way causal } \\
\text { relationship between the two. }\end{array}$ \\
\hline Ghartey (1993) & $\begin{array}{l}\text { United States, Japan and } \\
\text { Taiwan cross-section data }\end{array}$ & $\begin{array}{l}\text { American GDP promoted its } \\
\text { export, but Taiwan } \\
\text { is quite the opposite and there was } \\
\text { a two-way causal relationship } \\
\text { between the two in Japan }\end{array}$ \\
\hline $\begin{array}{l}\text { Jordan Shan and Fiona Sun } \\
\text { (1998) }\end{array}$ & $\begin{array}{l}\text { There is no relationship between } \\
\text { the two variables }\end{array}$ \\
\hline Jung and Marshall (1985) & Causalitty test & $\begin{array}{l}\text { No relationship between growth } \\
\text { and trade openness }\end{array}$ \\
\hline Chengxiang Shen (1999) & $\begin{array}{l}\text { Two way relationship between } \\
\text { trade and growth but no long term } \\
\text { relationship. }\end{array}$ \\
\hline
\end{tabular}

Source: Chen(2009)

\section{Data and models}

\footnotetext{
${ }^{3}$ Frankel, Jeffrey A. and David Romer (1999). "Does Trade Cause Growth?” The American Economic Review, (June) 379-399.
} 
In this sample we use data for 208 regions and countries (See Appendix 1 Descriptive statistics) actually variables are collected from the data set uste in one study ${ }^{4}$.We employ neo-classical framework in out models:

$$
\log y_{i}(t)-\log y_{i}(0)=\gamma_{0}+\gamma_{1} \log y_{1}(0)+\gamma_{2} \log \left(n_{i}+g+\delta\right)+\gamma_{3} \log K+\gamma_{4} \log H+\gamma_{5} \operatorname{TrOpen+\varepsilon _{i}}(\mathbf{1})
$$

This model is suggested by Mankiw et all(1992), the left had side expression is the first difference logarithm of real GDP per worker between 1960 to 2000, other right hand side $y_{1}$ represents initial output, while $\mathbf{n}_{\mathbf{i}}+\mathbf{g}+\boldsymbol{\delta}$ are population growth, technological growth and depreciation in each country or region respectively, $K$ and $H$ represents both the physical and human capital accumulation. The term TrOpen denotes country i's degree of trade openness. Following MRW, we assume that the sum of rates of depreciation and technological progress is constant and equal to 0.05 across countries. We use real investment to GDP as proxy for physical capital and secondary school enrolment rate as proxy for human capital as recommended by MRW (1992). We employ OLS technique to estimate this cross-country regression results are presented in Table 1

\section{Table 1 Economic Growth and Trade Volumes: OLS Estimation results}

We start our estimations with the ratio of trade volume to GDP. We obtain two measures for this variable: one is from the World Bank and the other is from Penn World Tables (Version 6.1). One advantage of the World Bank measure is that the data are published in terms of exports and imports. Thus, this allows us to investigate the export-growth connection and import- growth connection separately. On the other hand the trade ratio of the Penn World Tables is published only as a sum of exports and imports at current prices. This is known as current opennes. Columns 1 and 2 show the regression results using the ratio of exports and the ratio of imports, respectively. Column 3 includes the trade ratio as a sum of the ratio of exports and the ratio of imports. In each regression the coefficient of the openness variable using world bank data is positive but not statistically significant, but Penn world table data current and real openness coefficient is positive and statistically significant suggesting that $10 \%$ increase in the trade ration will increase the growth by $2.7 \%$ over the period 1960-2000. In summary, the regression results in Table 1 show a positive association between economic growth and international trade and confirm the fiindings of previous work ${ }^{5}$. Physical and human capital are positively associated across all five models. Convergence and initial levels of capital are negatively associated with growth which is consistent with neo-classical growth theory ${ }^{6}$ In the next scatter we identify outliers in the scatter real openness vs growth.

\footnotetext{
${ }^{4}$ Bülent Ulaşan, 2012, "Openness to International Trade and Economic Growth: A Cross-Country Empirical Investigation [Dataset]", http://hdl.handle.net/1902.1/18245 UNF:5:2bZyPUz4MN/u7sAKORnl5A== Economics: The Open-Access, Open-Assessment E-Journal [Distributor] V3 [Version]
}

\footnotetext{
${ }^{5}$ Vamwakidis (2002), Dollar and Kraay (2003), Yanikkaya (2003), Alcala and Ciccone (2004) are a few examples.
}

${ }^{6}$ One of the main implications of Solow-type neoclassical growth models (Solow 1956) is a notion of "convergence" according to which developing countries grow faster than developed countries given the growth rates of technology and population. In particular, if countries are similar with respect to structural parameters, neoclassical growth models predict that a country's per capita growth rate tends to be negatively related to its starting level of income per person. (Fukuda, Toya,1995). 
Dushka Jasheski \& Darka Lazarav/GRP International Jaurnal of Business and Economics Vol.I №.2, 20।2

\begin{tabular}{|c|c|c|c|c|c|c|c|c|c|c|c|}
\hline \multirow[t]{2}{*}{ Variables } & \multirow{2}{*}{$\begin{array}{l}\text { Variables } \\
\text { definition }\end{array}$} & \multicolumn{10}{|c|}{$\begin{array}{l}\text { Dependent variable is GDPGR6020 log difference of real GDP per worker between } 1960 \text { and } \\
2000 .\end{array}$} \\
\hline & & 1 & t-stat & 2 & t-stat & 3 & t-stat & 4 & t-stat & 5 & t-stat \\
\hline LY1960 & $\begin{array}{l}\text { log GDP per } \\
\text { worker } 1960\end{array}$ & -0.43 & -7.63 & -0.46 & -7.43 & -0.46 & -7.59 & -0.46 & -7.53 & -0.43 & -7.03 \\
\hline LNGD & $\log \left(n_{i}+g+\delta\right)$ & -1.10 & -2.73 & -1.06 & -2.61 & -1.08 & -2.66 & -1.02 & -3.01 & -1.10 & -3.02 \\
\hline LINV & $\begin{array}{l}\text { log of } \\
\text { Investment } \\
\text { rate }\end{array}$ & 0.36 & 3.04 & 0.40 & 2.99 & 0.40 & 3.01 & 0.34 & 3.08 & 0.36 & 3.44 \\
\hline LSCH & $\begin{array}{l}\text { log of School } \\
\text { enrolment }\end{array}$ & 0.43 & 4.98 & 0.45 & 5.16 & 0.45 & 5.1 & 0.44 & 6.12 & 0.43 & 6.02 \\
\hline XGDP_WB & $\begin{array}{l}\text { Exports ratio } \\
\text { of WB }\end{array}$ & 0.27 & 1.24 & - & - & - & - & - & - & - & - \\
\hline MGDP_WB & $\begin{array}{l}\text { Imports } \\
\text { ratio of WB }\end{array}$ & - & - & 0.32 & 1.10 & - & - & - & - & - & - \\
\hline XMGDP_WB & $\begin{array}{l}\text { Trade ratio } \\
\text { of WB }\end{array}$ & - & - & - & - & 0.18 & 1.19 & - & - & - & - \\
\hline ROPEN & $\begin{array}{l}\text { Real } \\
\text { Openness }\end{array}$ & - & - & - & - & - & - & 0.40 & 3.57 & - & - \\
\hline COPEN & $\begin{array}{l}\text { Current } \\
\text { Openness }\end{array}$ & - & - & - & - & - & - & - & - & 0.27 & 2.46 \\
\hline _cons & constant & 2.24 & 2.34 & 2.73 & 2.32 & 2.72 & 2.33 & 2.73 & 2.84 & 2.24 & 2.25 \\
\hline \multicolumn{2}{|c|}{ Number of observations } & \multicolumn{4}{|c|}{93} & \multicolumn{2}{|c|}{93} & \multicolumn{2}{|c|}{105} & \multicolumn{2}{|c|}{105} \\
\hline R-squared & & \multicolumn{2}{|c|}{0.6257} & & 6231 & \multicolumn{2}{|c|}{0.6248} & \multicolumn{2}{|c|}{ n.a } & \multicolumn{2}{|c|}{0.6486} \\
\hline
\end{tabular}

(a) Real Openness: Exports plus Imports as a ratio of GDP in PPP

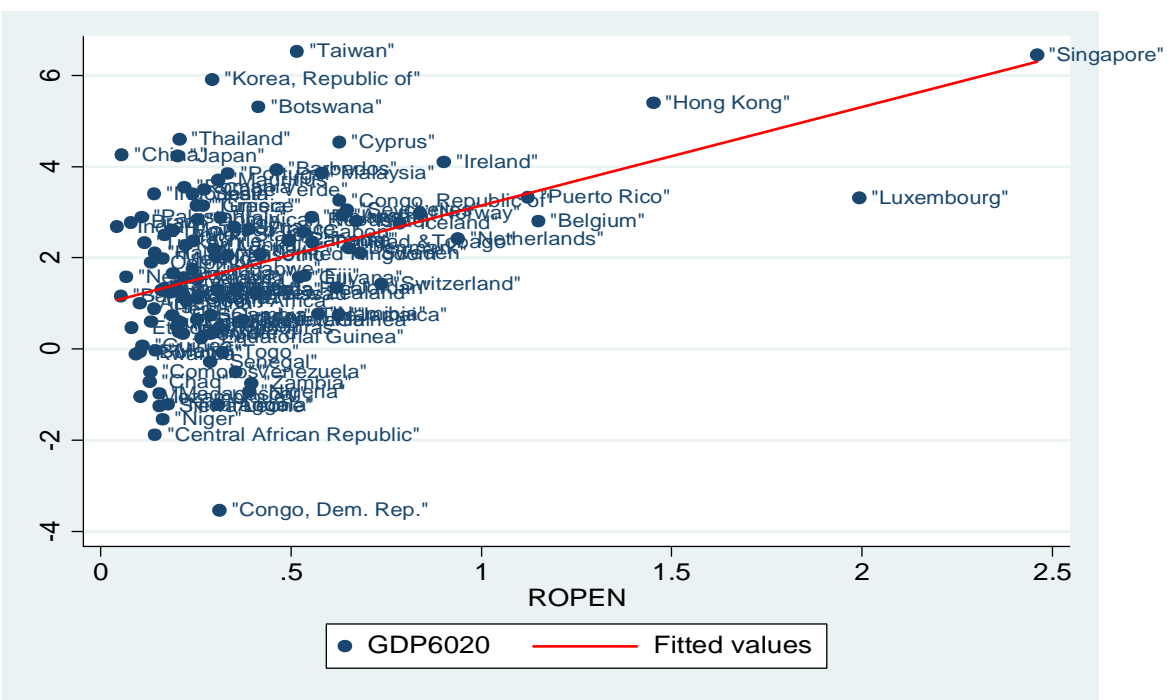

(b) Current Openness: Exports plus Imports as a ratio of GDP in current prices

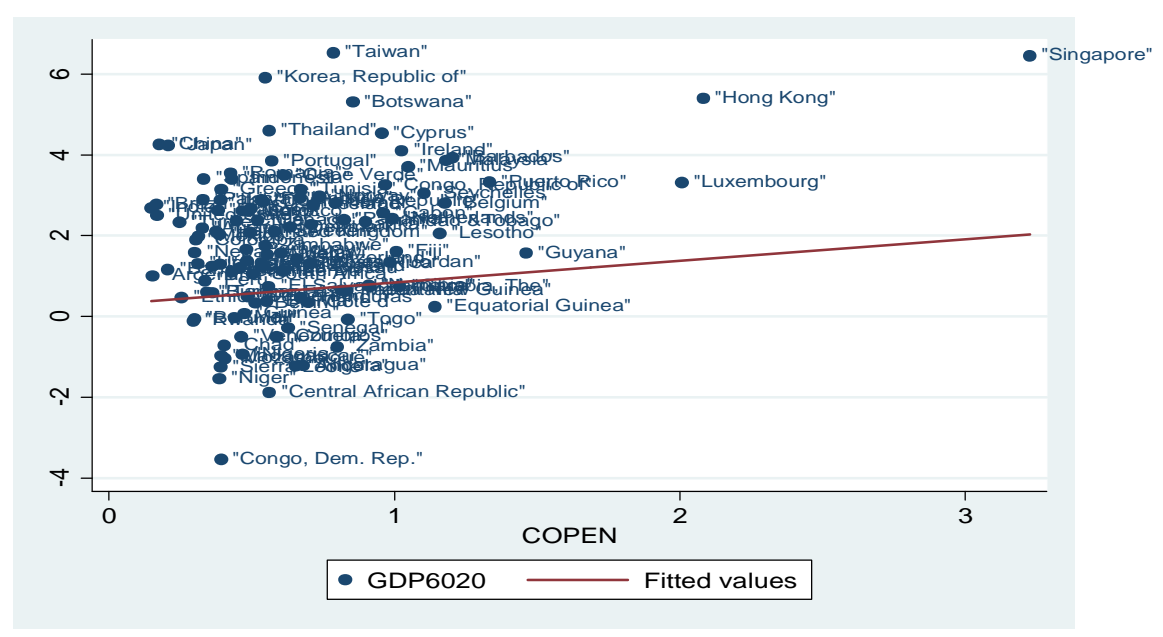


On the previous scatter we identify Singapore, Hong Kong, and Luxembourg as outliers. Their outstanding characteristics are that they have the highest trade ratios with an average value of 244 percent according to the current openness and experience very high growth performances over the sample period.

\section{Direct Trade Policy Measures and economic growth}

In the second step we investigate the openness-growth connection by employing direct trade policy measures namely tariff rates, non-tariff barriers on imports ${ }^{7}$

Table 2 Economic Growth and Direct Trade Measures: OLS Estimates

\begin{tabular}{|c|c|c|c|c|c|c|c|c|c|}
\hline \multirow[t]{2}{*}{ Variables } & \multirow[t]{2}{*}{ Variables definition } & \multicolumn{8}{|c|}{$\begin{array}{c}\text { Dependent variable is GDPGR6020 log difference of real GDP per worker between } \\
1960 \text { and } 2000 .\end{array}$} \\
\hline & & 1 & t-stat & 2 & t-stat & 3 & t-stat & 4 & t-stat \\
\hline LY1960 & $\begin{array}{l}\text { log GDP per worker } \\
1960\end{array}$ & -0.49 & -6.76 & -0.48 & -7.05 & 0.083 & -5.38 & -0.48 & -6.13 \\
\hline LNGD & $\log (n i+g+\delta)$ & -1.29 & -3.07 & -1.27 & -3.12 & 0.443 & -2.5 & -1.06 & -2.8 \\
\hline LINV & log of Investment rate & 0.43 & 3.18 & 0.43 & 3.19 & 0.153 & 2.89 & 0.4 & 3.35 \\
\hline LSCH & $\begin{array}{l}\text { log of School } \\
\text { enrolment }\end{array}$ & 0.42 & 4.52 & 0.43 & 4.93 & 0.091 & 4.89 & 0.448 & 5.44 \\
\hline OWTI & $\begin{array}{l}\text { Own-import weighted } \\
\text { tariff rates, 1983-1985 } \\
\text { period }\end{array}$ & -0.33 & -1.08 & - & - & - & - & - & - \\
\hline OWQI & $\begin{array}{l}\text { Own-import weighted } \\
\text { non-tariff barriers, } \\
\text { 1983-1985 period }\end{array}$ & - & - & -0.12 & -0.6 & - & - & - & - \\
\hline M_DUTY & $\begin{array}{l}\text { Collected import } \\
\text { duties } 8\end{array}$ & - & - & - & - & 0.997 & 0.38 & - & - \\
\hline UWATR & $\begin{array}{l}\text { Unweighted average } \\
\text { tariff rate, 1990-99 } \\
\text { period. }\end{array}$ & - & - & - & - & - & - & -0.48 & -0.85 \\
\hline cons & constant & 2.56 & 2 & 2.50 & 2.04 & 1.542 & 1.72 & 3.109 & 2.35 \\
\hline \multicolumn{2}{|c|}{ Number of observations } & \multicolumn{2}{|c|}{87} & \multicolumn{2}{|c|}{85} & \multicolumn{2}{|c|}{93} & \multicolumn{2}{|c|}{101.00} \\
\hline \multicolumn{2}{|l|}{ R-squared } & \multicolumn{2}{|c|}{0.62} & \multicolumn{2}{|c|}{ n.a } & \multicolumn{2}{|c|}{0.58} & \multicolumn{2}{|c|}{0.63} \\
\hline
\end{tabular}

In columns 1 and 2 of Table 2, we only include tariff rate and non-tariff barriers, respectively. Both measures enter the regressions with negative but insignificant coefficient estimates. The coefficient on import duties is positive but statistically insignificant. It is well known fact that the ratio of collective import duties in a country's overall imports is a problematic measure in order to reflect a country's tariff structure due to the fact that a country with very high tariff rates may appear open by this measure.

\section{Black Market Premium: A Proxy for Trade Policy or Macroeconomic Imbalances?}

Most of the countries in Africa and Latin America experience higher levels of black market premium.

\footnotetext{
${ }^{7}$ It is obvious that the first two measures directly affect a country's trade volume and reducing or removing them clearly indicates a more open trade regime.

${ }^{8}$ Collected import duties as ratio of imports over 1970-1998 period
} 
3 Black Market premium and economic growth OSL estimates

\begin{tabular}{|c|c|c|c|c|c|c|c|c|c|}
\hline $\begin{array}{l}\text { Dependent variable is } \\
\text { GDPGR6020 log difference } \\
\text { of real GDP per worker } \\
\text { between } 1960 \text { and } 2000 .\end{array}$ & $\begin{array}{l}\text { Variables } \\
\text { definition }\end{array}$ & Coef. & $\mathrm{t}$ & Coef. & $\mathrm{t}$ & Coef. & $\mathrm{t}$ & Coef. & $\mathrm{t}$ \\
\hline LY1960 & $\begin{array}{l}\text { log GDP per } \\
\text { worker } 1960 \\
\end{array}$ & -0.53 & -6.5 & -0.51 & -7.48 & -0.48 & -7.36 & -0.50 & -7.37 \\
\hline LNGD & $\log (n i+g+\delta)$ & -1.09 & -2.88 & -1.25 & -3.65 & -1.05 & -3.12 & -1.11 & -3.19 \\
\hline LINV & $\begin{array}{l}\text { log of } \\
\text { Investment rate }\end{array}$ & 0.28 & 3.29 & 0.24 & 3.27 & 0.23 & 3.28 & 0.26 & 3.5 \\
\hline $\mathrm{LSCH}$ & $\begin{array}{l}\text { log of School } \\
\text { enrolment }\end{array}$ & 0.57 & 6.13 & 0.52 & 6.41 & 0.52 & 6.55 & 0.54 & 6.62 \\
\hline LogBMP60 & $\begin{array}{l}\log (1+\mathrm{BMP}) \text { in } \\
1960 \mathrm{~s}\end{array}$ & -0.16 & -1.39 & - & - & - & - & - & - \\
\hline LogBMP70 & $\begin{array}{l}\log (1+\mathrm{BMP}) \text { in } \\
1970 \mathrm{~s}\end{array}$ & - & - & -0.29 & -2.2 & - & - & - & - \\
\hline LogBMP80 & $\begin{array}{l}\log (1+\mathrm{BMP}) \text { in } \\
1980 \mathrm{~s}\end{array}$ & - & - & - & - & -0.20 & -3.21 & - & - \\
\hline LogBMP90 & $\begin{array}{l}\log (1+\mathrm{BMP}) \text { in } \\
1990 \mathrm{~s}\end{array}$ & - & - & - & - & - & - & -0.23 & -1.9 \\
\hline cons & constant & 3.22 & 2.97 & 2.57 & 2.57 & 2.86 & 2.91 & 2.93 & 2.83 \\
\hline \multicolumn{2}{|l|}{ Number of observations } & \multicolumn{2}{|c|}{93} & \multicolumn{2}{|c|}{107} & \multicolumn{2}{|c|}{107} & \multicolumn{2}{|c|}{107} \\
\hline \multicolumn{2}{|l|}{ R-squared } & \multicolumn{2}{|c|}{0.6061} & \multicolumn{2}{|c|}{0.6323} & \multicolumn{2}{|c|}{0.6505} & \multicolumn{2}{|c|}{0.628} \\
\hline
\end{tabular}

it is more likely that negative and significant connection between black market premium and economic growth over the period 1960-2000 reflects the adverse relation between macroeconomic imbalances and growth. Black market premium in 1960's,70's,80's,90's is negatively and statistically significantly associated with GDP growth $^{9}$.

\section{Macroeconomic policy variables}

First, we include two variables related to macroeconomic policy, namely inflation rate and government consumption expenditures. Inclusion of these variables is particularly important since an important criticism on the openness-growth literature is that openness measures are proxy for other macroeconomic policies rather than trade policy.

Table 4 Economic growth and macroeconomic policy variables including trade ratio as macroeconomic policy.

\begin{tabular}{|l|l|r|r|}
\hline \multicolumn{2}{|c|}{ Panel Between Effects models } & \\
\hline $\begin{array}{l}\text { Dependent variable is } \\
\text { GDPGR6020 log difference of } \\
\text { real GDP per worker between } \\
1960 \text { and 2000. }\end{array}$ & Variables definition & Coef. & t \\
\hline LY1960 & $\log$ GDP per worker 1960 & -0.36 & -3.35 \\
\hline LNGD & $\log \left(\mathbf{n}_{\mathbf{i}}+\mathbf{g}+\boldsymbol{\delta}\right)$ & -1.23 & -2.02 \\
\hline LINV & $\log$ of Investment rate & 0.58 & 3.72 \\
\hline LSCH & $\log$ of School enrolment & 0.35 & 2.4 \\
\hline XMGDP_WB & Trade ratio by World Bank & 0.37 & 2.21 \\
\hline INFLATION & inflation rate & 0.12 & 1.36 \\
\hline GOVCONS & government consumption/GDP & 0.48 & 0.33 \\
\hline cons & constant & 1.45 & 0.81 \\
\hline Number of observations & & & \multicolumn{2}{|c|}{0.65} \\
\hline R-squared(0verall) & & & \\
\hline
\end{tabular}

\footnotetext{
${ }^{9}$ This mainly depends on the high level and high variation in the black market premium during the 1980s in which many developing countries launched the liberalisation programs after the debt crises in the late 1970s and the early 1980 s.
} 
Trade ratio as proxy for openness in such environment is positive and statistically significant unlike macroeconomic variables that are insignificant.

\section{Institutions effect on economic growth}

We measure institutional quality by using a composite index based on the data set of International Country Risk Guide $(\mathrm{ICRG})^{10}$.

Table 5 Institutions as factor on economics growth vs trade openness

\begin{tabular}{|l|l|c|c|}
\hline \multicolumn{3}{|c|}{ Panel Between Effects models } & \\
\hline $\begin{array}{l}\text { Dependent variable is } \\
\text { GDPGR6020 log difference of } \\
\text { real GDP per worker between } \\
1960 \text { and 2000. }\end{array}$ & Variables definition & Coef. & t \\
\hline LY1960 & log GDP per worker 1960 & -0.30 & -2.44 \\
\hline LNGD & $\log (\mathbf{n i}+\mathbf{g}+\boldsymbol{\delta})$ & -1.52 & -2.32 \\
\hline LINV & log of Investment rate & 0.61 & 3.78 \\
\hline LSCH & log of School enrolment & 0.28 & 1.65 \\
\hline XMGDP_WB & Trade ratio by World Bank & 0.26 & 1.2 \\
\hline INFLATION & inflation rate & 0.16 & 1.73 \\
\hline GOVCONS & government consumption/GDP & -1.10 & -0.68 \\
\hline ICGR & Institutional Quality Index based on the & 0.15 & 2.12 \\
\hline Cons & constant & -0.26 & -0.12 \\
\hline Number of observations & & & 41 \\
\hline R-squared(0verall) & & & 0.67 \\
\hline
\end{tabular}

Coefficient on the institutions proxy variable is positive and statistically significant, while coefficient on trade in the presence of institutions variable has diminished significance and it is insignificant.

\section{Conclusion (resume)}

Overall trade openness has positive effect on economic growth, black market premium as a proxy for imbalance in macroeconomic policies has negative effect, in the presence of macroeconomic policies (government consumption and inflation) trade has statistically and economic significant positive influence on growth, and in an institutional environment trade lacks influencing growth, the coefficient on institutions is positive and statistically significant.

\footnotetext{
10 Published by a private international consulting company Political Risk Services, this index consists of equally weighting an average of four ICRG components for the years 1984-2000: i) investment profile as a average of three subcomponents namely, contract viability, profits repatriation and payment delays; ii) law and order; iii) corruption; and iv) bureaucratic quality.
} 


\section{Appendix 1 Descriptive statistics of the variables}

\begin{tabular}{|c|c|c|c|c|c|}
\hline Variable & Variables definitions & Obs & Mean & Std. Dev. & Min \\
\hline GDPGR6020 & $\begin{array}{l}\text { Log difference real GDP per worker } \\
\text { btw } 1960 \text { and } 2000\end{array}$ & 118 & 0.67284 & 0.663944 & -1.35254 \\
\hline LY1960 & Log of Real GDP per worker in 1960 & 118 & 8.315269 & 0.838991 & 6.573731 \\
\hline LNGD & $\begin{array}{l}\text { Log of sum of rates of population } \\
\text { growth, TP and depreciation over } \\
1960-2000 \text { period. }\end{array}$ & 191 & -2.67835 & 0.166289 & -3.06888 \\
\hline LINV & $\begin{array}{l}\text { Log of Average investment share in } \\
\text { GDP at constant prices over the } 1960 \text { - } \\
2000 \text { period. }\end{array}$ & 116 & -2.00554 & 0.605964 & -3.87963 \\
\hline $\mathrm{LSCH}$ & $\begin{array}{l}\text { Log of Average secondary school } \\
\text { enrolment rate over the } 1960-2000 \\
\text { period. }\end{array}$ & 125 & -1.01186 & 0.848931 & -3.11522 \\
\hline MGDP_WB & $\begin{array}{l}\text { Imports share by the World Bank } \\
\text { (MGDP WB) }\end{array}$ & 107 & 0.337736 & 0.188695 & 0.072298 \\
\hline XGDP_WB & Exports share by the World Bank & 107 & 0.295786 & 0.18485 & 0.065576 \\
\hline XMGDP_WB & Trade ratio by World Bank & 107 & 0.633522 & 0.358251 & 0.145264 \\
\hline COPEN & Current Openness of Penn World & 114 & 0.643167 & 0.416541 & 0.147656 \\
\hline ROPEN & Real Openness of Penn World & 114 & 0.373446 & 0.352563 & 0.043561 \\
\hline OWTI & $\begin{array}{l}\text { Own-import weighted tariff rates, } \\
\text { 1983-1985 period }\end{array}$ & 104 & 0.168817 & 0.162973 & 0 \\
\hline OWQI & $\begin{array}{l}\text { Own-import weighted non-tariff } \\
\text { barriers, } 1983-1985 \text { period }\end{array}$ & 102 & 0.185794 & 0.237151 & 0 \\
\hline M_DUTY & Collected import duties & 117 & 0.12293 & 0.088828 & 0 \\
\hline $\operatorname{logBMP} 6020$ & $\log (1+\mathrm{BMP}), 1960-2000$ period. & 121 & 0.377613 & 0.671639 & -0.00443 \\
\hline $\operatorname{logBMP} 60$ & $\log (1+\mathrm{BMP})$ in 1960s. & 103 & 0.213121 & 0.409949 & -0.0009 \\
\hline $\operatorname{logBMP70}$ & $\log (1+\mathrm{BMP})$ in 1970s. & 121 & 0.232322 & 0.346003 & -0.07214 \\
\hline $\operatorname{logBMP} 80$ & $\log (1+\mathrm{BMP})$ in 1980s. & 121 & 0.398824 & 0.634852 & -0.0142 \\
\hline $\operatorname{logBMP90}$ & $\log (1+\mathrm{BMP})$ in 1990s. & 121 & 0.274288 & 0.7994 & -0.00351 \\
\hline UWATR & $\begin{array}{l}\text { Unweighted average tariff rate, 1990- } \\
99 \text { period }\end{array}$ & 121 & 0.149564 & 0.093249 & 0.0032 \\
\hline ICGR & $\begin{array}{l}\text { Institutional Quality Index based on } \\
\text { the ICRG data }\end{array}$ & 124 & 3.77601 & 1.144813 & 1.11152 \\
\hline INFLATION & $\begin{array}{l}\text { Average Inflation Rate over the 1960- } \\
2000 \text { period }\end{array}$ & 118 & 0.399947 & 1.257691 & 0.02486 \\
\hline GOVCONS & Government Consumption & 121 & 0.155383 & 0.05326 & 0.059789 \\
\hline
\end{tabular}

\section{References}

Andy C. C \& KwanJohn A. (1991). Cotsomitis. Economic Growth and the Expanding Export Sector: China 1952-1985,International Economic Journal, 5(1): 105 - 116.

Bülent Ulaşan, (2012), "Openness to International Trade and Economic Growth: A Cross-Country Empirical Investigation ", Economics: The Open-Access, Open-Assessment E-Journal [Distributor]

Chen,Huan (2009), A Literature Review on the Relationship between Foreign Trade and Economic Growth,International journal of economics and finance 
Dollar, David and Kraay, Aart, Growth is Good for the Poor (April 2001). World Bank Policy Research Working Paper No. 2587.

Ghartey. E. E. (1993). Casual Relationship between Exports and Economic Growth: Some Empirical Evidence innTaiwan, Japan and the US, Applied-Economics. (9): 1145-1152

Jung, S. W., Marshall. Exports (1985). Growth and Causality in Developing Countries. Journal of Development Economics, (18):1-12.

Mankiw,Romer,Weil(1992), Acontribution to the empirics of the economic growth, The quarterly journal fo economics, Vol107,Issue,2 pp.407-437

Frankel, Jeffrey A. and David Romer (1999). "Does Trade Cause Growth?" The American Economic Review, (June) 379-399.

Robert, M. Solow (1956) "A Contribution to the Theory of Economic Growth" Quarterly Journal of Economics. Vol. 70 (1) pp. 65-94.

Shan \& Fiona Sun. (1998). On The Export-led Growth Hypothesis: The Econometric Evidence From China. Applied Economics, (30).

Shan, J. \& F. Sun. (1998b). On the Export-led Growth Hypothesis: The econometricEvidence from China. Applied Economics, 30: 1055-1065.

Fukuda,S., Hideki,T.,(1995), Conditional Convergence in East Asian Countries: The Role of Exports in Economic Growth, University of Chicago Press, ISBN: 0-226-38670- 